\title{
Effect of drying on the hydroxyl accessibility and sorption properties of pressurized hot water extracted wood
}

\author{
Suvi Kyyrö ${ }^{1}$ D Michael Altgen ${ }^{1,2} \cdot$ Hanna Seppäläinen ${ }^{1} \cdot$ Tiina Belt $^{3}$. \\ Lauri Rautkari ${ }^{1}$
}

Received: 15 February 2021 / Accepted: 31 May 2021 / Published online: 19 June 2021

(c) The Author(s) 2021

\begin{abstract}
Hot water extraction (HWE) treatment changes the physicochemical properties of the wood, including hygroscopic properties. HWE treatment decreases the hydroxyl accessibility of the wood, but the relevance of other mechanisms that change hygroscopic properties are not fully understood. This study investigates the effect of drying on the hydroxyl accessibility and sorption properties of wood. Pressurized hot water extraction (HWE) treatment was applied at $140{ }^{\circ} \mathrm{C}$ for $1-5 \mathrm{~h}$ to Scots pine (Pinus sylvestris L.) sapwood samples in order to remove increasingly more hemicellulose from the cell wall matrix. Following HWE treatment, half of the wood samples were oven-dried and then re-soaked, while the other half was kept in a fully saturated state. The samples were investigated by applying a new approach that was based on the deuteration of accessible hydroxyl groups, which was followed by the measurement of mass loss due to re-protonation. Sorption properties of the wood samples were studied by measuring moisture content, sorption isotherms and dimensional changes. The present results showed that accessible hydroxyl group content decreased only due to hemicellulose removal during the HWE treatment and was unaffected by oven-drying. However, oven-drying enhanced the effect of HWE treatments in reducing the water-saturated dimensions and the moisture content of wood. Therefore, the additional reductions in hygroscopicity and water-saturated dimensions were not related to changes in sorption site density.
\end{abstract}

Suvi Kyyrö

suvi.kyyro@aalto.fi

1 Department of Bioproducts and Biosystems, School of Chemical Engineering, Aalto University, P.O. Box 16300, 00076 Aalto, Finland

2 Department of Biology, Institute of Wood Science, Wood Physics, Universität Hamburg, Leuschnerstraße 91C, 21031 Hamburg, Germany

3 Natural Resources Institute Finland, Production Systems, Tietotie 2, 02150 Espoo, Finland 


\section{Introduction}

Wood is a hygroscopic material that takes up moisture depending on its surrounding conditions. Under stable environmental conditions wood absorbs or desorbs water until it attains equilibrium moisture content (EMC). Changes in moisture content (MC) affect many physical properties of wood, which makes the reduction in hygroscopicity a topic of interest in the wood modification field. Several studies have explored the mechanisms behind the reduced hygroscopicity of hydrothermally modified wood (Borrega and Kärenlampi 2010; Altgen et al. 2016, 2018a; Wentzel et al. 2018). Previous studies conclude that the hygroscopicity of wood is linked to the presence of accessible polar groups, i.e. hydroxyl $(\mathrm{OH})$ groups, which act as sorption sites for water (Venkateswaran 1970; Berthold et al. 1996). However, besides the sorption site density, further mechanisms also influence the sorption behaviour of thermally modified wood (Repellin and Guyonnet 2005; Borrega and Kärenlampi 2010; Rautkari et al. 2013; Altgen et al. 2016, 2018a; Wentzel et al. 2018). Therefore, hydrothermal treatments of wood affect the sorption of wood not only by reduction of accessible $\mathrm{OH}$ groups due to changes in chemical composition, but also by other mechanisms that are not fully understood.

Treating wood with pressurized hot water within the temperature range of $100-240{ }^{\circ} \mathrm{C}$ causes the preferential cleavage and extraction of hemicellulosebased carbohydrates, which simultaneously increases cellulose and lignin content in the solid residue (Wikberg et al. 2015; Nitsos et al. 2016; Kyyrö et al. 2020). Pressurized hot water extraction (HWE) reduces the concentration of accessible $\mathrm{OH}$ groups $\left(\mathrm{OH}_{\mathrm{acc}}\right)$, and consequently, the moisture content of the treated wood (Boonstra and Tjeerdsma 2006). However, drying of the HWE-treated wood is likely to additionally affect the moisture content. Results by Altgen et al. (2018a) showed that the water-saturated dimensions of wood blocks did not decrease after HWE, because water occupied the space in the cell wall that was previously occupied by the extracted hemicelluloses. When the treated wood was oven-dried and then re-soaked with water, the water-saturated dimensions decreased as a function of the removed wood mass. This was assigned to enhanced cellulose aggregation and hydrogen bonding in HWE-treated wood during oven-drying, which restricted the uptake of water by the cell wall (Seborg et al. 1953; Altgen et al. 2018b; Lillqvist et al. 2019).

Cellulose aggregation has been investigated extensively in relation to pulp behaviour (Hult et al. 2001; Pönni et al. 2012; Salmén and Stevanic 2018). Removing the hemicellulose and lignin that act as spacers between adjacent cellulose microfibrils enhances cellulose aggregation during drying. The bonded cellulose microfibril areas resist the swelling forces during re-soaking, which reduces the water retention of the dried pulp fibres (Hult et al. 2001; Pönni et al. 2012). Although there is clear evidence for a drying effect on the water-related properties of pulp and thermally treated wood, there is uncertainty about the underlying modes of action. Previous studies have suggested that the cell wall bound water in pulps correlates with the number of accessible hydroxyl groups 
(Pönni et al. 2014a) and that the drying of pulps reduces the hydroxyl accessibility (Pönni et al. 2012). Suchy et al. (2010) suggested that a similar effect also occurs during the first drying of wood. In contrast, studies on native Norway spruce found that full water-saturation can almost completely eliminate the reduction in hydroxyl accessibility and hygroscopicity caused by drying (Hoffmeyer et al. 2011; Thybring et al. 2017). Furthermore, Salmén and Stevanic (2018) found that microfibril aggregation and a loss in water retention caused by drying were not accompanied by a loss in hydroxyl accessibility in pulp fibres. A reason for such contradictory results may be the lack of an adequate method for measuring the amount of accessible $\mathrm{OH}$ groups in dried and never-dried wood. Therefore, alternative methods are required for measuring the effects of first drying on hydroxyl accessibility.

The hydroxyl accessibility in wood can be determined by utilizing deuterated water $\left(\mathrm{D}_{2} \mathrm{O}\right.$, "heavy water") in gravimetric (Taniguchi et al. 1978; Rautkari et al. 2013; Altgen et al. 2018a) and spectroscopic analyses (Fackler and Schwanninger 2011) or both (Thybring et al. 2017, 2020). Exposing wood to $\mathrm{D}_{2} \mathrm{O}$ causes the exchange of hydrogen from accessible $\mathrm{OH}$ groups to deuterium (deuteration). This exchange is reversible (re-protonation) by exposure to water $\left(\mathrm{H}_{2} \mathrm{O}\right)$. The conversion of $\mathrm{OH}-\mathrm{OD}$ groups can be studied by the changes in $\mathrm{OH}$ and $\mathrm{OD}$ stretching vibrations located at different wavenumber ranges in the infrared spectrum. These band changes can be utilized to determine the relative hydroxyl accessibility by relating the intensity of the OD stretching band to the combined $\mathrm{OH}+\mathrm{OD}$ stretching band intensities (Hofstetter et al. 2006; Suchy et al. 2010; Fackler and Schwanninger 2011). However, relative hydroxyl accessibility does not provide information on the concentration of accessible $\mathrm{OH}$ groups. This concentration can be determined by recording the dry mass gain of ca. $1 \mathrm{~g} \mathrm{~mol}^{-1}$ per exchanged hydrogen during the deuteration of lignocelluloses (Wadehra and Manley 1966; Pönni et al. 2014b). However, this gravimetric approach requires the measurement of the initial dry sample mass, and, therefore, cannot be utilized for the determination of the accessible $\mathrm{OH}$ group concentration in never-dried samples.

The present study investigates the effect of first drying on the hydroxyl accessibility and sorption properties of HWE-treated wood. A new approach was applied that was based on the deuteration of accessible $\mathrm{OH}$ groups in liquid $\mathrm{D}_{2} \mathrm{O}$, which was followed by the measurement of mass loss due to re-protonation in $\mathrm{H}_{2} \mathrm{O}$ vapour. This novel approach was used to study how the removal of hemicelluloses by HWE affects the hydroxyl accessibility of wood both before and after subsequent water removal by oven-drying. The effects of drying on the sorption properties of HWE-treated wood were also investigated by measuring moisture content, sorption isotherms and dimensional changes. HWE treatment was applied at $140{ }^{\circ} \mathrm{C}$ for $1-5 \mathrm{~h}$ to never-dried Scots pine sapwood (Pinus sylvestris L.) blocks, which were either preserved in the never-dried state (ND) or dried and re-soaked in water (DR). The present results show that the accessible $\mathrm{OH}$ group concentration of wood was solely affected by chemical composition changes, while the water vapour sorption and swelling of the wood were also significantly affected by the intermediate drying. 


\section{Material and methods}

\section{Material}

All samples were cut from same 70-year-old fresh Scots pine (Pinus sylvestris L.) wood log previously stored at $-20{ }^{\circ} \mathrm{C}$. Cut samples were sapwood with approximate dimensions of $7 \times 7 \times 14 \mathrm{~mm}^{3}(\mathrm{R} \times \mathrm{T} \times \mathrm{L})$. An average moisture content of $105 \pm 4.5 \%$ was determined on a separate set of samples. The samples did not contain heartwood, knots or other visible defects. The samples were evenly distributed between eight treatment groups. Each treatment group consisted of three samples. Figure 1 summarizes the treatment procedure and the utilized analytical methods.

\section{Pressurized hot water extraction, drying and re-soaking}

All wood samples were fully soaked in deionized water overnight and the water-saturated dimensions measured. The two reference groups were not HWE-treated. All other samples and deionized water (solid:liquid ratio approximately 1:25 g/g) were put into tightly sealed $225 \mathrm{ml}$ steel vessels and HWE-treated at $140{ }^{\circ} \mathrm{C}$ for different time periods: $1 \mathrm{~h}, 3 \mathrm{~h}$ or $5 \mathrm{~h}$. The HWE treatment was performed in a rotating silicon oil-bath reactor (Haato, Model 43,427). The reference and HWE-treated samples were leached for two weeks in deionized water that was changed every second day. After leaching, the dimensions of all samples were measured. $60 \mu \mathrm{m}$ microtome slices (Microtome Nahita ZFP-011) were swiftly cut from the radial surface of half

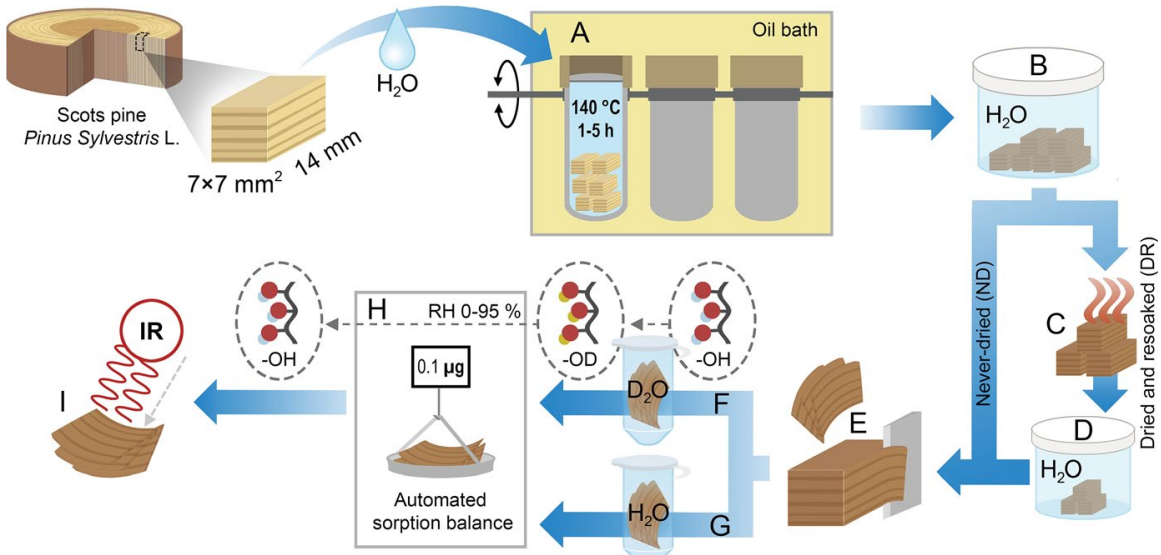

Fig. 1 Treatment procedure for Scots pine sapwood samples $\left(7 \times 7 \times 14 \mathrm{~mm}^{3}, \mathrm{R} \times \mathrm{T} \times \mathrm{L}\right)$ : A Hot water extraction treatment, $\mathbf{B}$ water-leaching, $\mathbf{C}$ oven-drying (only dried and re-soaked, DR, samples), $\mathbf{D}$ resoaking (only dried and re-soaked, DR, samples), E cutting $60 \mu \mathrm{m}$ microtome slices from radial surface of never-dried (ND) and dried and re-soaked (DR) samples, F deuteriation of $60 \mu \mathrm{m}$ microtome slices for hydroxyl accessibility measurement in liquid $\mathrm{D}_{2} \mathrm{O}$, $\mathbf{G}$ storage of $60 \mu \mathrm{m}$ microtome slices for sorption isotherm measurement in liquid $\mathrm{H}_{2} \mathrm{O}, \mathbf{H}$ gravimetric analysis with automated sorption balance and $\mathbf{I}$ spectroscopic analysis 
of the samples, which served as the never-dried (ND) sample groups. These samples were taken from one reference group and three sample groups HWE-treated for $1 \mathrm{~h}, 3 \mathrm{~h}$ and $5 \mathrm{~h}$. Leftover wood was used for chemical composition analysis. The other half of the samples were oven-dried first at $40{ }^{\circ} \mathrm{C}$ for $24 \mathrm{~h}$ and then at $105{ }^{\circ} \mathrm{C}$ for another $24 \mathrm{~h}$. After intermediate drying, the samples were water-saturated with deionized water under vacuum (50 mbar for $24 \mathrm{~h}$ ). The dimensions of these dried and rewet (DR) samples were measured. After water saturation, $60 \mu \mathrm{m}$ microtome slices were swiftly cut from the radial surface of DR samples. Leftover wood was used for chemical composition analysis.

\section{Chemical composition}

Chemical composition was determined for all wood sample groups. Wood was ground in Wiley mill to pass through a 30 mesh screen. Moisture content was measured from ground wood based on SFS-EN 13183-1 (2002). Extractives were removed from ground powder with $150 \mathrm{ml}$ acetone in a Soxhlet apparatus according to standard method TAPPI T $204 \mathrm{~cm}-97$ (2007). Structural carbohydrates and lignin were determined from extracted wood according to NREL/TP-510-42,618 (Sluiter et al. 2012). The monosaccharide composition of the hydrolysate was analysed with High-Performance Anion-Exchange Chromatography with Pulsed Amperometric Detection (HPAEC-PAD), as previously described by Lillqvist et al. (2019). Monosaccharide composition was used to determine cellulose and hemicellulose content, as previously described by Janson (1970). Chemical composition measurements were taken in duplicates.

\section{Sorption isotherm analysis}

Sorption isotherms were measured from reference samples and samples HWEtreated for $5 \mathrm{~h}$. The measurements were taken shortly after the HWE treatments on microtome slices that were kept in deionized water at $4{ }^{\circ} \mathrm{C}$. The method for measuring desorption-absorption cycles was adapted from Fredriksson and Thybring (2018). Measurements were performed with automated sorption balance (DVS Advantage ET, Surface Measurement Systems, UK). During the measurements, the $\mathrm{N}_{2}$ flow and the target temperature were kept constant at $200 \mathrm{sccm}$ and $25{ }^{\circ} \mathrm{C}$, respectively. For each measurement, three slices were quickly wiped with a moist cloth to remove excess water and then placed on the sample pan of the sorption balance. Sorption isotherms were recorded starting with desorption from the watersaturated state by applying the following steps: (A) 95\% target RH for $60 \mathrm{~h}$; (B) 75\% target RH for $24 \mathrm{~h}$; (C) $55 \%$ target RH for $12 \mathrm{~h}$; (D) $35 \%$ target RH for $12 \mathrm{~h}$; (E) $0 \%$ target $\mathrm{RH}$ for $24 \mathrm{~h}$. The absorption sequence was performed in reverse by increasing target $\mathrm{RH}$ stepwise to $95 \%$ (steps D-C-B-A). After the desorption-absorption sequences, the samples were dried using the pre-heater in the automated sorption balance. The temperature was first gradually increased from 25 to $60{ }^{\circ} \mathrm{C}$ within $1 \mathrm{~h}$, kept at $60{ }^{\circ} \mathrm{C}$ for $6 \mathrm{~h}$ and finally gradually decreased back to $25^{\circ} \mathrm{C}$ within $1 \mathrm{~h}$. The 
dry mass was recorded after a $2 \mathrm{~h}$ stabilization period at $25^{\circ} \mathrm{C}$. The final mass at the end of each RH step was used for the MC (in \%) calculation according to Eq. 1:

$$
\mathrm{MC}=\left(\mathrm{m}_{\mathrm{RH}}-\mathrm{m}_{\mathrm{dry}}\right) /\left(\mathrm{m}_{\mathrm{dry}}\right)
$$

where $m_{R H}$ is the mass of wood sample at the end of the respective RH step and $m_{\text {dry }}$ is the mass of wood sample at the end of stabilization period following the drying with pre-heater.

\section{Quantification of accessible hydroxyl groups by re-protonation}

Wet $60 \mu \mathrm{m}$ microtome slices were submerged and stored in $1.5 \mathrm{ml}$ of deuterium oxide (99.9\%, Sigma-Aldrich) in closed containers. Deuterium oxide was changed twice during a week to ensure that all accessible $\mathrm{OH}$ groups in the microtome slices were exchanged for OD groups. These samples were stored in the fridge at $4{ }^{\circ} \mathrm{C}$ prior to the re-protonation experiments.

$\mathrm{OH}$ accessibility was gravimetrically measured from microtome slices with an automated sorption balance (DVS Advantage ET, Surface Measurement Systems, $\mathrm{UK}$ ) with $0.1 \mu \mathrm{g}$ accuracy. During the measurements, the $\mathrm{N}_{2}$ flow and the target temperature were kept constant at $200 \mathrm{sccm}$ and $25{ }^{\circ} \mathrm{C}$, respectively. Three microtome slices were used for each measurement. Automated sorption balance measurement consisted of a four-step sequence: (A) exposure to $\mathrm{D}_{2} \mathrm{O}$ vapour at $95 \%$ target $\mathrm{RH}$ for $12 \mathrm{~h}$; (B) drying under $\mathrm{N}_{2}$ flow for $24 \mathrm{~h}$; (C) exposure to $\mathrm{H}_{2} \mathrm{O}$ vapour at $95 \%$ target $\mathrm{RH}$ for $12 \mathrm{~h}$; (D) drying under $\mathrm{N}_{2}$ flow for $24 \mathrm{~h}$. Following the final sequence step, dry $\mathrm{N}_{2}$ gas flow was kept at $75 \mathrm{sccm}$ until the samples were removed from the automated sorption balance apparatus. Figure 2 shows the changes in mass (mg) of one wood sample (3 h HWE, ND) as a function of time (h) throughout the automated sorption balance sequence. To confirm the applicability of this method, additional untreated wood slices, which were kept in liquid $\mathrm{H}_{2} \mathrm{O}$, were subjected to the same RH steps in a different order: (C), (D), (A) and (B). Thereby, the slices were deuterated and not re-protonated.

Fig. 2 Changes in mass (mg) of one wood sample ( $3 \mathrm{~h} \mathrm{HWE}$, never-dried) as a function of time (h) throughout the automated sorption balance sequence

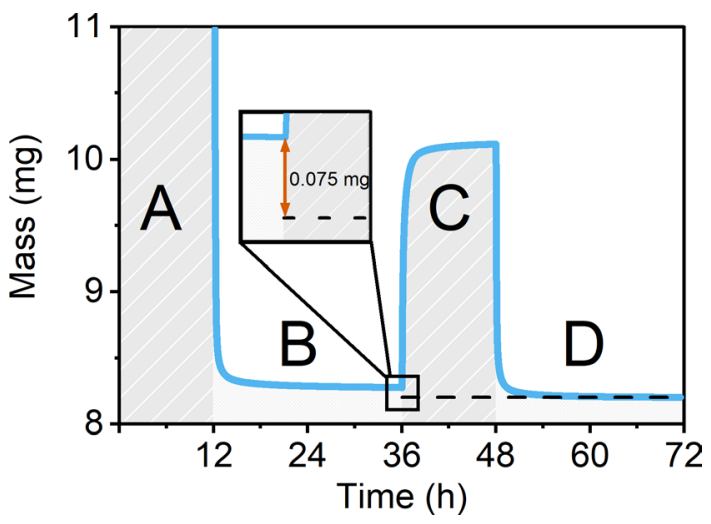


The concentration of accessible $\mathrm{OH}$ groups $\left(\mathrm{OH}_{\mathrm{acc}}\right.$, in $\left.\mathrm{mmol} \mathrm{g}^{-1}\right)$ was determined based on the dry mass difference between the deuterated and the re-protonated state using Eq. 2:

$$
\mathrm{OH}_{\mathrm{acc}}=1000 \times\left(\mathrm{m}_{\mathrm{B}}-\mathrm{m}_{\mathrm{D}}\right) /\left(\Delta \mathrm{M} \times \mathrm{m}_{\mathrm{D}}\right)
$$

where $m_{B}$ and $m_{D}$ are the mass of the wood sample $(\mathrm{mg})$ at the end of steps B and D, respectively, and $\Delta \mathrm{M}$ is the atomic mass difference between deuterium and protium $\left(1.006 \mathrm{~g} \mathrm{~mol}^{-1}\right)$.

The moisture content (in mmol g ${ }^{-1}$ ) of the samples at $25{ }^{\circ} \mathrm{C}$ and $95 \% \mathrm{RH}$ was determined by using the masses at the end of the water vapour exposure step $\mathrm{C}$ and drying step D (Fig. 2) according to Eq. 3:

$$
\mathrm{MC}=1000 \times\left(\mathrm{m}_{\mathrm{C}}-\mathrm{m}_{\mathrm{D}}\right) /\left(\mathrm{m}_{\mathrm{D}} \times \mathrm{M}_{\text {water }}\right)
$$

where $m_{C}$ and $m_{D}$ are the mass of the wood sample at the end of steps $C$ and $D$, and $\mathrm{M}_{\text {water }}$ is the molar mass of $\mathrm{H}_{2} \mathrm{O}\left(18.01528 \mathrm{~g} \mathrm{~mol}^{-1}\right)$. All measurements were performed in triplicate.

\section{Spectroscopic analysis on re-protonated samples}

The re-protonated microtome slices were removed from the automated sorption apparatus within $24 \mathrm{~h}$ after the end of the measurement sequence. To limit water vapour absorption, the time between removal from the dry $\mathrm{N}_{2}$ atmosphere of the sorption apparatus and the recording of the Fourier transform infrared (FTIR) spectra under ambient laboratory conditions was minimised. FTIR spectra were also measured from microtome slices prepared from reference wood that were deuterated with $\mathrm{D}_{2} \mathrm{O}$ vapour. The spectra were measured on a FTIR spectrometer (Spectrum Two, PerkinElmer, USA) and an ATR unit that was equipped with a diamond crystal. Spectra were measured from three different sample points in the interval $600-4000 \mathrm{~cm}^{-1}$ using a spectral resolution of $4 \mathrm{~cm}^{-1}$ and 8 accumulations. The $\mathrm{OH}$ and OD band intensities were quantified by integration of the spectra in the interval 3000-3700 $\mathrm{cm}^{-1}$ and $2400-2700 \mathrm{~cm}^{-1}$, respectively (Hofstetter et al. 2006). The relative hydroxyl accessibility, $\mathrm{OD} /(\mathrm{OH}+\mathrm{OD})$, was calculated as described by Thybring et al. (2017).

\section{Results and discussion}

\section{Chemical composition and dimensional changes}

In line with previous studies (e.g. Kyyrö et al. 2020; Nitsos et al. 2016; Wikberg et al. 2015), HWE treatment caused a decrease in hemicellulose content and an increase in cellulose and lignin content due to the preferential degradation of hemicelluloses (Table 1). Slightly larger contents of cellulose and hemicelluloses and lower contents of lignin were recorded for the never-dried sample group than 
Table 1 Chemical compositions of HWE-treated Scots pine sapwood samples

\begin{tabular}{|c|c|c|c|c|c|}
\hline $\begin{array}{l}\text { HWE dura- } \\
\text { tion (h) }\end{array}$ & Cellulose $\%$ & Lignin \% & $\begin{array}{l}\text { Hemicellulose } \\
\text { hexosan \% }\end{array}$ & $\begin{array}{l}\text { Hemcellulose } \\
\text { pentosan } \%\end{array}$ & $\begin{array}{l}\text { Acetone soluble } \\
\text { extractives } \%\end{array}$ \\
\hline \multicolumn{6}{|l|}{ Never-dried } \\
\hline 0 & 43.6 & 26.5 & 19.7 & 10.1 & 1.3 \\
\hline 1 & 44.4 & 27.9 & 18.8 & 9.3 & 1.1 \\
\hline 3 & 47.3 & 29.5 & 16.6 & 8.2 & 0.9 \\
\hline 5 & 50.6 & 30.3 & 14.3 & 7.6 & 1.1 \\
\hline \multicolumn{6}{|c|}{ Dried and re-soaked } \\
\hline 0 & 40.4 & 28.3 & 18.6 & 9.6 & 1.0 \\
\hline 1 & 42.9 & 28.6 & 18.9 & 8.4 & 0.7 \\
\hline 3 & 45.3 & 31.4 & 16.3 & 7.7 & 0.6 \\
\hline 5 & 48.9 & 31.1 & 13.4 & 7.3 & 0.7 \\
\hline
\end{tabular}

Lignin \% includes both Klason and acid soluble lignin

for the dried and re-soaked sample group. However, these differences were also evident in the reference samples and were small compared to the effects of HWE treatment. The chemical composition results confirmed that variations in hemicellulose content were not largely affected by intermediate drying.

The irreversible effect of intermediate drying was evident from the changes in the relative wet dimensions of the samples (Fig. 3). Relative changes in the longitudinal dimension were minor $(\leq 0.6 \%)$ even when the HWE treatment time was $5 \mathrm{~h}$ and intermediate drying was applied. Since relative changes in radial and tangential dimensions were more prominent $(\leq 3.2 \%)$, measurements from the crosssectional area were deemed sufficient for measuring the relative wet dimensions. To calculate relative wet dimensions, the final water-saturated cross-sectional area was divided by the water-saturated cross-sectional area before HWE treatment. For the ND samples, the final water-saturated area was measured immediately after HWE treatment, while for the DR samples it was determined after drying and re-soaking.

Fig. 3 Relative wet dimensions (radial $\times$ tangential; after/before HWE) of never-dried (ND) and dried and re-soaked (DR) samples (Error bars show the standard deviation)

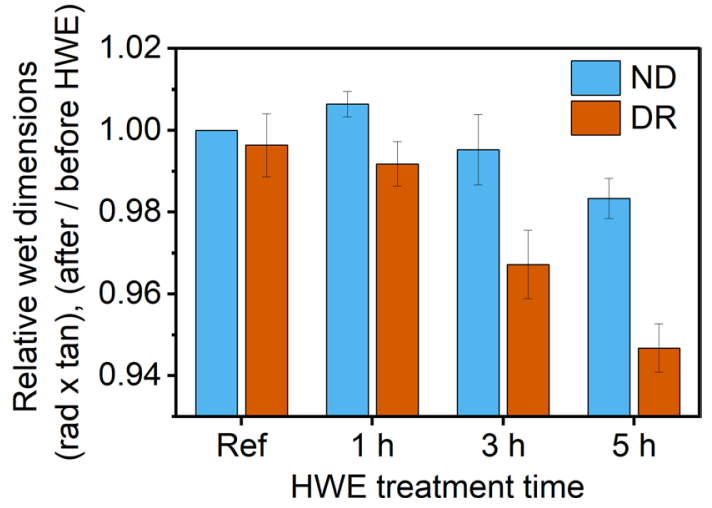


The relative wet dimensions of wood decreased with increasing HWE treatment time with the exception of the ND samples treated for $1 \mathrm{~h}$, which exhibited a minor increase in relative wet dimensions. The decrease in relative wet dimensions can be assigned to more extensive wood degradation during an extended treatment time. However, the decrease was very minor for the ND samples, while the application of intermediate drying resulted in a more prominent change. Even severely HWEtreated ND samples had relative wet dimensions of over 0.98 , presumably because water molecules filled the space created by the removal of degraded wood components (mainly hemicellulose, see Table 1). Oven-drying resulted in the shrinkage of wood due to the removal of water, and this effect was not completely reversed upon one re-saturation. The loss in water-saturated dimensions by drying and re-soaking increased with HWE treatment time, while reference samples nearly reverted to their prior relative wet dimensions upon re-saturation. Since the differences in the chemical composition between ND and DR were minor (Table 1), it is more likely that the additional reduction in the water-saturated dimensions of DR samples was caused by changes in the structural arrangement of the cell walls. Altgen et al. (2018a) obtained similar results and concluded, based on previous knowledge in the field of pulp and paper technology, that the removal of hemicelluloses between adjacent cellulose microfibrils during HWE treatments favoured cellulose aggregation during subsequent drying. They speculated that this may have restricted the swelling of the cell walls during re-soaking. This may also explain the loss in water-saturated wood block dimensions observed in the present study.

\section{Sorption isotherms and hysteresis}

Desorption and absorption isotherms were measured from reference samples and samples that were HWE-treated for $5 \mathrm{~h}$, either in the never-dried state or after drying and re-soaking (Fig. 4). The current procedure for determining sorption isotherms differed from previous studies on thermally treated wood, which started the isotherm measurements in absorption from the dry state followed by desorption from the conditioned state (Altgen et al. 2016; Kymäläinen et al. 2018; Lillqvist et al. 2019). As pointed out by Fredriksson and Thybring (2018), this procedure measures the desorption isotherm starting from a state that is neither dry nor fully saturated, and the resulting desorption isotherm is dependent on the previous sorption history. Instead, the current measurements started with desorption from the watersaturated state, and absorption from the dry state was measured thereafter. This procedure did not allow for an accurate determination of the sample mass change per minute during the measurements. However, for each RH step, the mass change over the final $60 \mathrm{~min}(\mathrm{dm} / \mathrm{dt})$ was determined after the measurements and did not exceed 14.31 $\mathrm{g} \mathrm{g} \mathrm{g}^{-1} \mathrm{~min}^{-1}$ (see Supplementary Table S.1). Although this rate is relatively small in view of previous dynamic vapour sorption measurements, it is reasonable to assume that some deviation from the equilibrium state remained. As an example, Glass et al. (2018) reported that the application of a stop criterion of $5 \mu \mathrm{g} \mathrm{g}^{-1} \mathrm{~min}^{-1}$ to dynamic water vapour sorption measurements of loblolly pine wood resulted in absolute errors in EMC as high as 0.8-0.9\%. Nonetheless, the residual sample mass 
Fig. 4 Sorption isotherms of the reference and severely HWEtreated (5 h) a never-dried (ND) and $\mathbf{b}$ dried and re-soaked (DR) samples

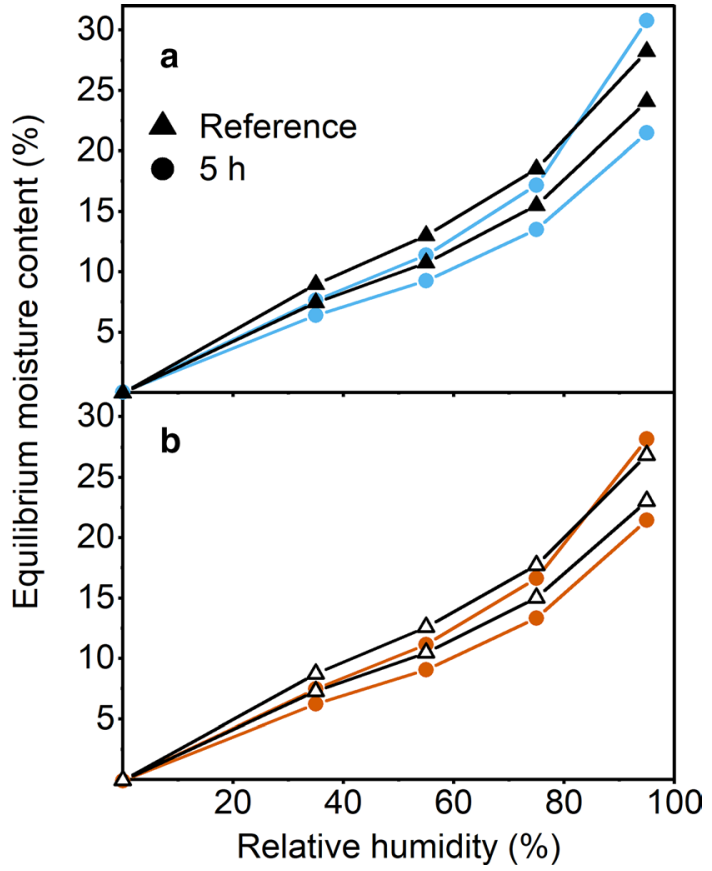

changes per minute determined in the present study were considerably lower than the stop criterion of $\geq|10| \mu \mathrm{g} \mathrm{g}^{-1} \mathrm{~min}^{-1}$, which had been applied in previous studies on the sorption behaviour of heat-treated wood (Altgen et al. 2016; Hill et al. 2012; Wentzel et al. 2018).

The effect of the HWE treatment differed between desorption and absorption isotherms, which could be observed from the sorption results of both DR and ND samples. During desorption from the water-saturated state, the MC of the HWE-treated samples exceeded the MC of the reference samples at a $\mathrm{RH}$ of $95 \%$ but decreased below the reference $\mathrm{MC}$ when the $\mathrm{RH}$ was reduced to $75 \%$ or lower. During absorption from the dry state, the MC of HWE-treated wood remained below the reference MC over the entire RH range. This behaviour cannot be solely explained by a decrease in $\mathrm{OH}$ group content, nor by irreversible cellulose aggregation upon drying. Although both factors may play a role, they are inconsistent with the higher MC of HWE-treated wood at 95\% RH during desorption. Instead, the sorption behaviour may be explained by the temperature- and moisture-dependent state of the amorphous cell wall polymers. As summarized by Engelund et al. (2013), the softening of water-saturated lignin requires temperatures above $60-70{ }^{\circ} \mathrm{C}$, but watersaturated hemicelluloses are above their softening point even at room temperature. In this state, the viscosity and rigidity of the polymeric network are low, which is expected to increase the capacity of the cell wall to accommodate water (Engelund et al. 2013). Hydrolysis during HWE may have increased the free space between the polymers and reduced the hemicellulose chain length to further decrease the rigidity of the polymeric network (Altgen et al. 2016), which presumably caused the 
increase in MC of HWE-treated wood during the initial desorption from the watersaturated state. When the $\mathrm{RH}$ was decreased, the water-filled structure collapsed due to cell wall shrinkage and the polymeric network became rigid as its moisture content decreased below the softening point. In this state, HWE-treated wood had a lower MC than the reference samples. Potentially, the loss in hemicelluloses and the consequent decrease in the sorption site density became the more dominant factor below the softening point.

In view of a possible deviation between the measured MC and the actual EMC, it cannot be fully ruled out that the observed differences in $\mathrm{MC}$ were affected by the holding times that were limited to $60 \mathrm{~h}$ or less. This is particularly true because the resulting sample mass change per minute $(\mathrm{dm} / \mathrm{dt})$ at the end of the RH steps was not uniform. However, a systematic difference in $\mathrm{dm} / \mathrm{dt}$ between reference and HWE-treated samples was not observed (see Supplementary Table S.1). Furthermore, it was noticed that the MC difference between treated and reference samples at $95 \% \mathrm{RH}$ clearly exceeded the absolute error in EMC of $0.8-0.9 \%$ or less that was reported by Glass et al. (2018) for untreated loblolly pine at a dm/dt of $5 \mu \mathrm{g} \mathrm{g}^{-1} \mathrm{~min}^{-1}$. Nonetheless, a time-dependent effect may have contributed to the observed results to some extent and requires further analyses.

Re-exposure of dried wood to water vapour does not fully re-open the collapsed wood structure (Thybring et al. 2017; Fredriksson and Thybring 2019). This explains why the MC of the HWE-treated wood remained below the reference MC when the RH was raised back to $95 \%$ during absorption (Fig. 4). The inability of water vapour to re-open the HWE-treated cell wall also explains the strong increase in the sorption hysteresis from 75 to $95 \% \mathrm{RH}$, which is in contrast to the nearly linear increase in hysteresis of the reference samples (Fig. 5).

The nearly complete re-opening of the dried cell wall may be achieved by vacuum-impregnation or prolonged soaking in liquid water (Hoffmeyer et al. 2011; Thybring et al. 2017; Fredriksson and Thybring 2019). However, a small, yet measurable difference in $\mathrm{MC}$ of dried and re-soaked samples compared to never-dried samples has recently been reported by Penttilä et al. (2020) and Altgen and Rautkari (2021). In line with these previous studies, a slightly lower MC at $95 \% \mathrm{RH}$ during desorption was observed for DR compared to ND reference samples $(\Delta \mathrm{MC}$

Fig. 5 Sorption hysteresis of the reference and severely HWEtreated $(5 \mathrm{~h})$ never-dried (ND) and dried and re-soaked (DR) samples

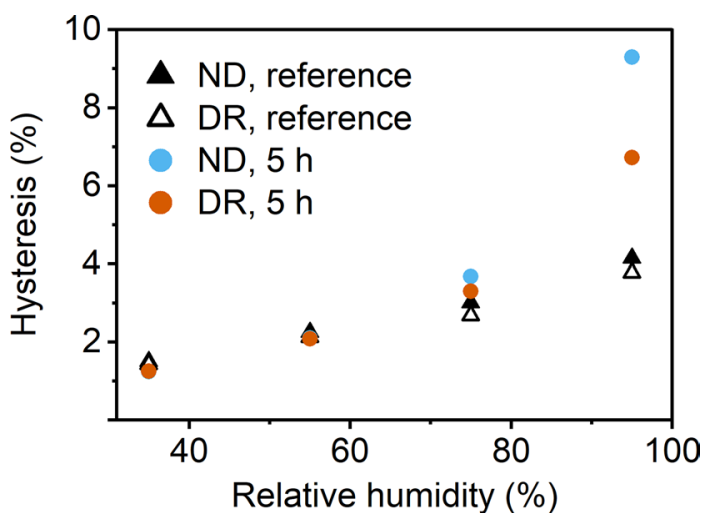

Springer 
ca. 1.4\%). This permanent drying effect increased in HWE-treated wood, which can be seen in the larger MC difference between DR and ND samples during the initial desorption ( $\triangle \mathrm{MC}$ ca. $2.6 \%$ ) and in a lower maximum hysteresis for DR samples compared to ND samples (Fig. 5). As mentioned above, it is possible that the error in determining the EMC by the limited holding times in the sorption balance had an effect and this also applies to the MC difference between ND and DR samples. However, the observed effect of intermediate oven-drying is in line with the aforementioned decrease in water-saturated dimensions of the HWE-treated wood blocks after drying and re-soaking. A reduction in $\mathrm{MC}$ after the first drying was also observed for untreated wood by Penttilä et al. (2020), who found permanent changes in the nanostructure of the cell walls using X-ray and neutron scattering. They speculated that the shrinking water-swollen polysaccharide matrix pulled the cellulose microfibrils closer to each other but also contracted the microfibrils in their longitudinal direction, which caused them to bend or twist. Full water-saturation could not fully erase these structural changes. It seems plausible that this effect was stronger in HWE-treated wood because the removal of hemicelluloses would increase the shrinkage of the cell wall during oven-drying to further disturb the order of the cellulose chains.

\section{Moisture content and hydroxyl accessibility}

The re-protonation experiments were conducted on slices that were taken from the $\mathrm{ND}$ and DR wood blocks and deuterated by soaking in liquid $\mathrm{D}_{2} \mathrm{O}$. In the automated sorption balance, the slices were first exposed to $\mathrm{D}_{2} \mathrm{O}$ vapour at $95 \%$ and dried under dry $\mathrm{N}_{2}$ flow before they were re-protonated in $\mathrm{H}_{2} \mathrm{O}$ vapour at $95 \% \mathrm{RH}$ and then dried again. The mass loss from the initial to the final drying step was used to quantify the concentration of (deuterated) $\mathrm{OH}$ groups that were accessible to water vapour, while the sample mass during the exposure to $\mathrm{H}_{2} \mathrm{O}$ vapour was used to determine the MC at $95 \%$ RH (Fig. 6).

In line with previous studies on hydrothermal treatments of wood (Altgen et al. 2016, 2018b; Kymäläinen et al. 2018; Altgen and Rautkari 2021), the sample MC decreased with increasing treatment intensity, i.e. the HWE treatment time (Fig. 6a). Furthermore, the MC was strongly affected by the intermediate drying of the DR samples. Similar to the relative wet dimensions (Fig. 3), longer HWE treatment times enhanced the effect of intermediate drying on the MC. The lower MC of the DR than ND samples is particularly interesting in view of the drying step applied prior to the conditioning of the slices at $95 \% \mathrm{RH} \mathrm{H}_{2} \mathrm{O}$ vapour. Therefore, the difference in $\mathrm{MC}$ can be assigned either to variations in drying conditions and/or the number of drying cycles. Oven-drying was performed on wood blocks at $40{ }^{\circ} \mathrm{C}$ for $24 \mathrm{~h}$ and then at $105{ }^{\circ} \mathrm{C}$ for $24 \mathrm{~h}$, while drying in the automated sorption apparatus was performed on thin slices at room temperature under dry $\mathrm{N}_{2}$ flow. As demonstrated by Salmén and Stevanic (2018), the drying method has an effect on the degree of cellulose microfibril aggregation since the rate of water removal affects the conformation of the cell wall polymers. It should be noted, however, that the conditioning step at $95 \% \mathrm{RH}$ (step C) was limited to $12 \mathrm{~h}$ and did not continue until a completely 
Fig. 6 a Moisture content $\mathrm{H}_{2} \mathrm{O}(\mathrm{MC})$ at $95 \% \mathrm{RH}$ and $25^{\circ} \mathrm{C}\left(\mathrm{mmol} \mathrm{g}^{-1}\right)$ and $\mathbf{b} \mathrm{OH}_{\text {acc }}$ $\left(\mathrm{mmol} \mathrm{g}^{-1}\right)$ of never-dried (ND) and dried and re-soaked (DR) samples as a function of HWE treatment time (Error bars show the standard deviation)
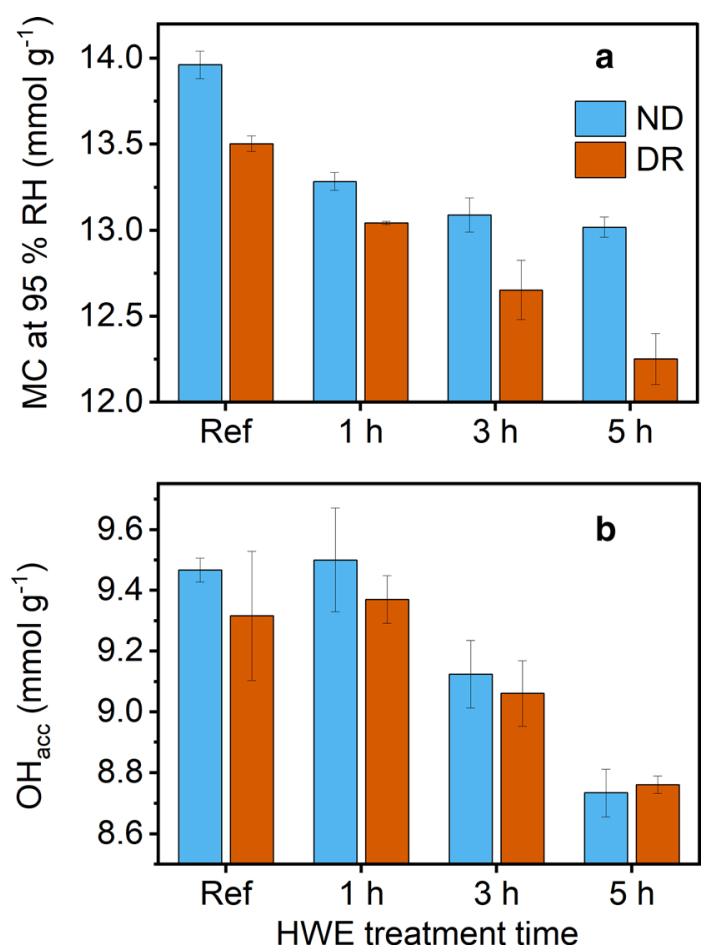

constant mass was reached. Although the sample mass changes per minute at the end of step C did not exceed $14.21 \mu \mathrm{g} \mathrm{g}^{-1} \mathrm{~min}^{-1}$, it is possible that the small effect of intermediate oven-drying on the $\mathrm{MC}$ was time-dependent. In addition to causing an actual reduction in EMC, the suggested cell wall changes caused by oven-drying may have delayed the attainment of the equilibrium state, so that absolute error in EMC at the end of the conditioning step was larger for DR samples.

The dry mass loss of the deuterated slices caused by the re-protonation in $\mathrm{H}_{2} \mathrm{O}$ vapour was utilized to calculate the concentration of accessible hydroxyl groups (Fig. 6b). The mass difference over the final $60 \mathrm{~min}(\mathrm{dm} / \mathrm{dt})$ at the end of the drying steps (steps B and D, see Fig. 2) did not exceed $11.61 \mathrm{~g} \mathrm{~g}^{-1} \mathrm{~min}^{-1}$ (see Supplementary Table S.2). Although this does not rule out the presence of residual $\mathrm{H}_{2} \mathrm{O}$ or $\mathrm{D}_{2} \mathrm{O}$ molecules completely, the residual mass change over time was significantly lower than the threshold of $5 \mu \mathrm{g} \mathrm{g}^{-1} \mathrm{~min}^{-1}$ that was recommended as a stop criterion for the drying step in deuterium exchange experiments by Uimonen et al. (2020). According to previous studies that measured the dry mass increase caused by deuteration, the average hydroxyl accessibility of Scots pine (Pinus sylvestris L.) sapwood varies between approx. 9 and $10.3 \mathrm{mmol} \mathrm{g}^{-1}$ (Digaitis et al. 2017; Altgen et al. 2018a). The present results on untreated wood fit within this range.

The results illustrated in Fig. 6b show that the hydroxyl accessibility of wood changed as a function of the HWE treatment time. Except for the shortest treatment time, the HWE treatment resulted in a decreased $\mathrm{OH}_{\text {acc }}$ content (Fig. 6b), which is consistent with previous research on the effect of hydrothermal treatment 
on hydroxyl accessibility and was assigned to a decrease in hemicellulose content (Boonstra and Tjeerdsma 2006; Altgen et al. 2018a). Figure 6a also shows that, contrary to the $\mathrm{MC}$ at $95 \% \mathrm{RH}$, the intermediate oven-drying of the DR samples had no major effect on the $\mathrm{OH}_{\text {acc }}$ content. This seems to be in contrast with a possible cellulose microfibril aggregation during drying. Although the aggregation of cellulose microfibrils provides a plausible explanation for the loss in watersaturated wood block dimensions by oven-drying, a loss in hydroxyl accessibility would be expected when adjacent microfibril surfaces are bonded together. It can only be speculated on the underlying changes of the cell wall ultrastructure, but the results of the current re-protonation experiments are in line with the results of Thybring et al. (2017) and Salmén and Stevanic (2018), who showed spectroscopically that drying does not cause changes in the relative hydroxyl accessibility in native wood and pulp fibres, respectively.

The successful re-protonation of deuterated wood samples was verified by FTIR spectroscopy. The relative hydroxyl accessibility of deuterated pre-test samples was only $30.3 \pm 1.8 \%$, which is about $5-10 \%$-points lower than the value observed in other studies (Fackler and Schwanninger 2011; Thybring et al. 2017). Altgen and Rautkari (2021) obtained similar results and assigned the low relative hydroxyl accessibility to re-protonation of easily accessible OD groups, which occurred shortly after sample removal from the automated sorption balance. Since such easily accessible OD groups would already be re-protonated during the $\mathrm{H}_{2} \mathrm{O}$ vapour exposure in the sorption balance, this effect was less critical during the actual test series.

The FTIR spectra that were collected from the re-protonated slices swiftly after the final drying step showed nearly no OD stretching vibrations, as shown by the lack of a clear signal at ca. $2500 \mathrm{~cm}^{-1}$ (see Supplementary Fig. S.3). The relative hydroxyl accessibility, which was calculated from the OH and OD stretching bands, ranged between 0 and $2.7 \%$ (see Supplementary Table S.4). Small amounts of OD groups that persisted even after long $\mathrm{H}_{2} \mathrm{O}$ exposure periods have been reported recently in native wood by Altgen and Rautkari (2021). After re-protonation of deuterated wood in $\mathrm{H}_{2} \mathrm{O}$ vapour, they measured relative $\mathrm{OH}$ accessibilities of less than $3 \%$, while gravimetrically determined amount of residual OD groups was ca. $0.5 \mathrm{mmol} \mathrm{g}{ }^{-1}$ or less. Therefore, it is reasonable to assume that the current gravimetric analysis was not distorted by residual OD groups after the re-protonation.

The measured MC at $95 \% \mathrm{RH}$ decreased linearly with decreasing $\mathrm{OH}_{\text {acc }}$ content, but the steepness of the regression curves differed between HWE-treated ND and DR samples (Fig. 7). As the $\mathrm{OH}_{\text {acc }}$ content decreased, the effect of intermediate drying on the reduction in $\mathrm{MC}$ at $95 \% \mathrm{RH}$ was enhanced. Reference samples interestingly did not fit into either linear function. These results show that the decreasing MC of HWE-treated DR samples at $95 \% \mathrm{RH}$ was not related to a further loss in $\mathrm{OH}_{\text {acc }}$ content. Similar findings were reported by Salmén and Stevanic (2018), who showed that a reduction in water retention and an increase in cellulose microfibril size due to drying were not accompanied by changes in relative $\mathrm{OH}$ accessibility in never-dried pulp fibres. Overall, the current observations were well in line with a number of recent studies, which showed that the accessible $\mathrm{OH}$ groups as sorption sites are not the main factor that determines the 
Fig. 7 Moisture content $\left(\mathrm{mmol} \mathrm{g}{ }^{-1}\right)$ as a function of accessible $\mathrm{OH}$ group content $\left(\mathrm{mmol} \mathrm{g}^{-1}\right)$ in the never-dried and dried and re-soaked DR samples

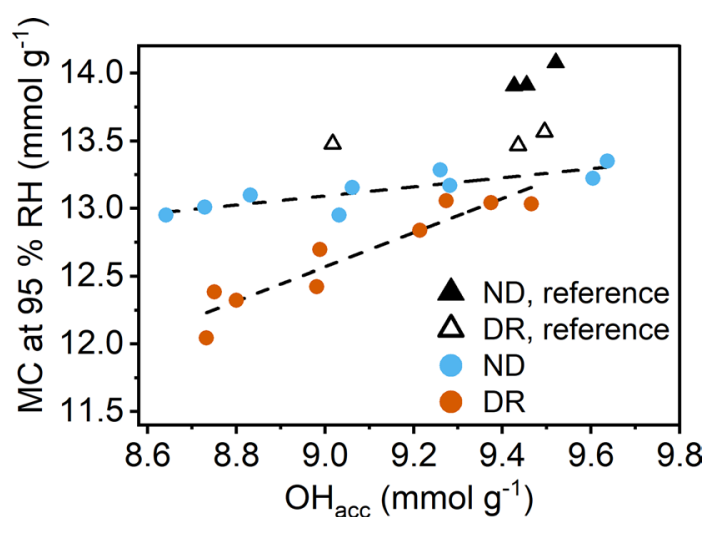

amount of absorbed water in native wood (Altgen and Rautkari 2021), thermally treated wood (Willems et al. 2020; Lillqvist et al. 2019) or chemically modified wood (Thybring et al. 2020).

\section{Conclusion}

Oven-drying enhanced the effect of HWE treatments in reducing the water-saturated dimensions and the moisture content of wood. This drying effect became more noticeable at longer HWE treatment times and could not be fully reversed by resoaking in water. Enhanced cellulose aggregation due to the removal of hemicellulose spacers and other nanostructural changes induced by the strong cell wall matrix shrinkage were discussed as potential reasons. However, by measuring the mass loss caused by the re-protonation of deuterated samples, it was shown that accessible $\mathrm{OH}$ group content decreased only due to hemicellulose removal during the HWE treatment and was unaffected by oven-drying. Therefore, the additional reductions in hygroscopicity and water-saturated dimensions on intermediate oven-drying were not related to changes in sorption site density.

Supplementary Information The online version contains supplementary material available at https://oi. org/10.1007/s00226-021-01307-4.

Acknowledgements Financial support from the Academy of Finland (grant No. 309881) and from the South Savo Regional Council of the European Regional Development Fund (project code A7389) is acknowledged.

Funding Open access funding provided by Aalto University.

\section{Declarations}

Conflict of interest The authors declare that they have no known competing financial interests or personal relationships that could have influenced the work reported in this paper. 
Ethical approval The authors declare that their study was done in accordance with the ethical standards. This article does not contain studies with human participants or animals. The contents of this study have not been published and are not currently being considered for publication elsewhere.

Open Access This article is licensed under a Creative Commons Attribution 4.0 International License, which permits use, sharing, adaptation, distribution and reproduction in any medium or format, as long as you give appropriate credit to the original author(s) and the source, provide a link to the Creative Commons licence, and indicate if changes were made. The images or other third party material in this article are included in the article's Creative Commons licence, unless indicated otherwise in a credit line to the material. If material is not included in the article's Creative Commons licence and your intended use is not permitted by statutory regulation or exceeds the permitted use, you will need to obtain permission directly from the copyright holder. To view a copy of this licence, visit http://creativecommons.org/licen ses/by/4.0/.

\section{References}

Altgen M, Rautkari L (2021) Humidity-dependence of the hydroxyl accessibility in Norway spruce wood. Cellulose 28:45-58. https://doi.org/10.1007/s10570-020-03535-6

Altgen M, Hofmann T, Militz H (2016) Wood moisture content during the thermal modification process affects the improvement in hygroscopicity of Scots pine sapwood. Wood Sci Technol 50:1181-1195. https://doi.org/10.1007/s00226-016-0845-X

Altgen M, Willems W, Hosseinpourpia R, Rautkari L (2018a) Hydroxyl accessibility and dimensional changes of Scots pine sapwood affected by alterations in the cell wall ultrastructure during heat-treatment. Polym Degrad Stab 152:244-252. https://doi.org/10.1016/j.polymdegradstab.2018.05.005

Altgen M, Uimonen T, Rautkari L (2018b) The effect of de- and re-polymerization during heat-treatment on the mechanical behavior of Scots pine sapwood under quasi-static load. Polym Degrad Stab 147:197205. https://doi.org/10.1016/j.polymdegradstab.2017.12.007

Berthold J, Rinaudo M, Salmeń L (1996) Association of water to polar groups; estimations by an adsorption model for ligno-cellulosic materials. Colloids Surf Physicochem Eng Asp 112:117-129. https://doi.org/ 10.1016/0927-7757(95)03419-6

Boonstra MJ, Tjeerdsma B (2006) Chemical analysis of heat treated softwoods. Holz Roh- Werkst 64:204211. https://doi.org/10.1007/s00107-005-0078-4

Borrega M, Kärenlampi P (2010) Hygroscopicity of heat-treated Norway spruce (Picea abies) wood. Eur J Wood Prod 68:233-235. https://doi.org/10.1007/s00107-009-0371-8

Digaitis R, Thybring EE, Künniger T, Thygesen LG (2017) Synergistic effects of enzymatic decomposition and mechanical stress in wood degradation. Wood Sci Technol 51:1067-1080. https://doi.org/10.1007/ s00226-017-0939-0

Engelund ET, Thygesen LG, Svensson S, Hill CAS (2013) A critical discussion of the physics of wood-water interactions. Wood Sci Technol 47:141-161. https://doi.org/10.1007/s00226-012-0514-7

Fackler K, Schwanninger M (2011) Accessibility of hydroxyl groups of brown-rot degraded spruce wood to heavy water. J Infrared Spectrosc 19:359-368. https://doi.org/10.1255/jnirs.943

Fredriksson M, Thybring EE (2018) Scanning or desorption isotherms? Characterising sorption hysteresis of wood. Cellulose 25:4477-4485. https://doi.org/10.1007/s10570-018-1898-9

Fredriksson M, Thybring EE (2019) On sorption hysteresis in wood: separating hysteresis in cell wall water and capillary water in the full moisture range. PLoS ONE 14:e0225111. https://doi.org/10.1371/journ al.pone.0225111

Glass SV, Boardmann CR, Thybring EE, Zelinka SL (2018) Quantifying and reducing errors in equilibrium moisture content measurements with dynamic vapour sorption (DVS) experiments. Wood Sci Technol 52:909-927. https://doi.org/10.1007/s00226-018-1007-0

Hill CAS, Ramsay J, Keating B, Laine K, Rautkari L, Hughes M, Constant B (2012) The water vapour sorption properties of thermally modified and densified wood. J Mater Sci 47:3191-3197. https://doi.org/10. 1007/s10853-011-6154-8

Hoffmeyer P, Engelund ET, Thygesen LG (2011) Equilibrium moisture content (EMC) in Norway spruce during the first and second desorptions. Holzforschung 65:875. https://doi.org/10.1515/hf.2011.112 
Hofstetter K, Hinterstoisser B, Salmén L (2006) Moisture uptake in native cellulose-the roles of different hydrogen bonds: a dynamic FT-IR study using Deuterium exchange. Cellulose 13:131-145. https://doi. org/10.1007/s10570-006-9055-2

Hult E-L, Larsson PT, Iversen T (2001) Cellulose fibril aggregation—an inherent property of kraft pulps. Polymer 42:3309-3314. https://doi.org/10.1016/S0032-3861(00)00774-6

Janson J (1970) Calculation of the polysaccharide composition of wood and pulp. Pap Ja Puu 52:323-329

Kymäläinen M, Mlouka SB, Belt T, Merk V, Liljeström V, Hänninen T, Uimonen T, Kostiainen M, Rautkari L (2018) Chemical, water vapour sorption and ultrastructural analysis of Scots pine wood thermally modified in high-pressure reactor under saturated steam. J Mater Sci 53:3027-3037. https://doi.org/10. 1007/s10853-017-1714-1

Kyyrö S, Altgen M, Rautkari L (2020) Pressurized hot water extraction of Scots pine sapwood: effect of wood size on obtained treatment products. Biomass Convers Biorefinery. https://doi.org/10.1007/ s13399-020-00927-3

Lillqvist K, Källbom S, Altgen M, Belt T, Rautkari L (2019) Water vapour sorption properties of thermally modified and pressurised hot-water-extracted wood powder. Holzforschung 73:1059-1068. https://doi. org/10.1515/hf-2018-0301

Nitsos CK, Choli-Papadopoulou T, Matis KA, Triantafyllidis KS (2016) Optimization of hydrothermal pretreatment of hardwood and softwood lignocellulosic residues for selective hemicellulose recovery and improved cellulose enzymatic hydrolysis. ACS Sustain Chem Eng 4:4529-4544. https://doi.org/10. 1021/acssuschemeng.6b00535

Penttilä PA, Altgen M, Carl N, van der Linden P, Morfin I, Österberg M, Schweins R, Rautkari L (2020) Moisture-related changes in the nanostructure of woods studied with X-ray and neutron scattering. Cellulose 27:71-87. https://doi.org/10.1007/s10570-019-02781-7

Pönni R, Vuorinen T, Kontturi E (2012) Proposed nano-scale coalescence of cellulose in chemical pulp fibers during technical treatments. BioResources 7:6077-6108. https://doi.org/10.15376/biores.7.4.6077-6108

Pönni R, Rautkari L, Hill CAS, Vuorinen T (2014a) Accessibility of hydroxyl groups in birch kraft pulps quantified by deuterium exchange in D2O vapour. Cellulose 21:2117-1226

Pönni R, Galvis L, Vuorinen T (2014b) Changes in accessibility of cellulose during kraft pulping of wood in deuterium oxide. Carbohydr Polym 101:792-797. https://doi.org/10.1016/j.carbpol.2013.10.001

Rautkari L, Hill CAS, Curling S, Jalaludin Z, Ormondroyd G (2013) What is the role of the accessibility of wood hydroxyl groups in controlling moisture content? J Mater Sci 48:6352-6356. https://doi.org/10. 1007/s10853-013-7434-2

Repellin V, Guyonnet R (2005) Evaluation of heat-treated wood swelling by differential scanning calorimetry in relation to chemical composition. Holzforschung 59:28-34. https://doi.org/10.1515/hf.2005.005

Salmén L, Stevanic JS (2018) Effect of drying conditions on cellulose microfibril aggregation and "hornification." Cellulose 25:6333-6344. https://doi.org/10.1007/s10570-018-2039-1

Seborg M, Tarkow H, Stamm AJ (1953) Effect of heat upon the dimensional stabilization of wood. J for Prod Res Soc 3:59-67

SFS-EN 13183-1 (2002) Moisture content of a piece of sawn timber. Part 1: Determination by oven dry method. Suomen standardisoimisliitto. Finnish Standards Association SFS

Sluiter A, Hames B, Ruiz R, Scarlata C, Sluiter J, Templeton D, Crocker C (2012) Determination of structural carbohydrates and lignin in biomass. National Renewable Energy Laboratory (NREL), USA

Suchy M, Virtanen J, Kontturi E, Vuorinen T (2010) Impact of drying on wood ultrastructure observed by deuterium exchange and photoacoustic FT-IR spectroscopy. Biomacromol 11:515-520. https://doi.org/ $10.1021 / \mathrm{bm} 901268 \mathrm{j}$

Taniguchi T, Harada H, Nakato K (1978) Determination of water adsorption sites in wood by a hydrogendeuterium exchange. Nature 272:230-231. https://doi.org/10.1038/272230a0

TAPPI T $204 \mathrm{~cm}-97$ (2007) Solvent extractives of wood and pulp. TAPPI Test Methods. Atlanta, GA

Thybring EE, Thygesen LG, Burgert I (2017) Hydroxyl accessibility in wood cell walls as affected by drying and re-wetting procedures. Cellulose. https://doi.org/10.1007/s10570-017-1278-x

Thybring EE, Piqueras S, Tarmian A, Burgert I (2020) Water accessibility to hydroxyls confined in solid wood cell walls. Cellulose 27:5617-5627. https://doi.org/10.1007/s10570-020-03182-x

Uimonen T, Hautamäki S, Altgen M, Kymäläinen M, Rautkari L (2020) Dynamic vapour sorption protocols for the quantification of accessible hydroxyl groups in wood. Holzforschung 74:412-419. https://doi. org/10.1515/hf-2019-0058

Venkateswaran A (1970) Sorption of aqueous and nonaqueous media by wood and cellulose. Chem Rev 70:619-637. https://doi.org/10.1021/cr60268a001 
Wadehra IL, Manley RSJ (1966) The accessibility of hydrocelluloses and oligosaccharides by hydrogen exchange. Makromol Chem 94:42-51. https://doi.org/10.1002/macp.1966.020940105

Wentzel M, Altgen M, Militz H (2018) Analyzing reversible changes in hygroscopicity of thermally modified eucalypt wood from open and closed reactor systems. Wood Sci Technol 52:889-907. https://doi.org/ 10.1007/s00226-018-1012-3

Wikberg H, Grönberg V, Jermakka J, Kemppainen K, Kleen M, Laine C, Paasikallio V, Oasmaa A (2015) Hydrothermal refining of biomass_an overview and future perspectives. Tappi J 14:195-207. https:// doi.org/10.32964/tj14.3.195

Willems W, Altgen M, Rautkari L (2020) A molecular model for reversible and irreversible hygroscopicity changes by thermal wood modification. Holzforschung 74:420-425. https://doi.org/10.1515/ hf-2019-0057

Publisher's Note Springer Nature remains neutral with regard to jurisdictional claims in published maps and institutional affiliations. 